\title{
PERIODIC REVIEW IN NATURAL RESOURCE CONTRACTS
}

\author{
Jacky Mandelbaum* \\ Salli Anne Swartz** \\ John Hauert****
}

\begin{abstract}
Periodic contract review mechanisms, which are provisions in contracts that formally require parties to meet at particular intervals to review the terms of the contract, are mechanisms that may facilitate the process of negotiating contractual changes to accommodate changing circumstances over the term of extractive industries contracts. Through the review of existing extractive industries agreements, this article considers how such review mechanisms have been incorporated into existing contracts and the use of such mechanisms as a tool for maintaining good relationships between the parties. In addition, the article suggests a new approach to the drafting of these mechanisms by negotiating objective criteria to be incorporated into the contract at the commencement of the contractual relationship in order to facilitate the timing and parameters of contract renegotiation when certain triggers occur.
\end{abstract}

Keywords: Periodic review, natural resources, extractive industries contracts, renegotiation, sustainable development, long-term contracts; hardship.

doi: http://dx.doi.org/10.4314/jsdlp.v6i2.6

* Special Counsel at a leading Australian law firm. Prior to that, Jacky worked for a number of years as a Senior Legal Researcher at the Columbia Centre for Sustainable Investment, a joint centre of the Columbia Law School and the Earth Institute at Columbia University in New York.

$* *$ A partner in the French firm Artus Wise and has been practicing international and French business law in Paris since 1979. She is a former Chair of the ABA International Section of Law, a member of the International Legal Assistance Consortium and has given advice to African governments for over 25 years in connection with the negotiation of extractive industry agreements. She works closely with the Columbia Centre on Sustainable Development, the International Senior Lawyers Project, the African Legal Support Facility, the Natural Resource Governance Institute and other NGOs.

$* * *$ Dr. iur. (University of Cologne), Master (Sciences Po), is a consultant at the Organisation for Economic Co-operation and Development(OECD). The views herein are those of the author and do not necessarily reflect those of the OECD. 


\section{INTRODUCTION}

Large-scale investments in extractive industries can be plagued by demands for renegotiation, sometimes leading to arbitration or litigation and causing a breakdown in the relationship between the host country and the investor. The nature of these investments - long-term, lasting for 20 to 50 years or longer - means that it can be difficult to predict at the outset what conditions will exist over the course of the investment. It is very likely that the circumstances at the time the original agreement is entered into will change, driven for example, by resource cycles or a changing political environment.

As the balance of risks and benefits changes, parties request modifications to the terms and conditions of the investment. Accordingly, mechanisms are needed in these agreements to smoothen the process of dealing with the inevitability of changing circumstances. "Periodic Review Mechanisms", provisions that formally require parties to meet at particular intervals to review the terms of the contract or licence and consider whether circumstances have changed since the parties' initial agreement, are one such mechanism.

Contractually provided periodic reviews give the parties an opportunity to negotiate and readjust contractual arrangements. Worst case scenarios often arise out of long-term frustration by one or several of the parties, which can result in expropriations with years of ensuing litigation or international arbitration. Provided that the parties take advantage of the opportunity to renegotiate terms, the contract terms and conditions can be readjusted before the parties are so desperate and frustrated that the investor decides to stop work or the Government decides to terminate permits and concessions.

Notably, our research does not suggest that Periodic Review Mechanisms are widely used. Nonetheless, forms of such mechanisms have been included in contracts as early as the 1970s. ${ }^{1}$ A review undertaken for the purpose of this brief of publicly available extractive industry contracts and of extractive industry databases ${ }^{2}$ identified such mechanisms only in contracts published

An abridged version of this article has been published at http://ccsi.columbia.edu/ files/2014/08/Periodic-review-in-natural-resource-contracts-Briefing-NoteFINAL-8.11.pdf and Mandelbaum, J., Swartz, S., and Hauert, J., "Sustainable Development and Natural Resources: Periodic Negotiations of Natural Resource Contracts", International Law News (2015) Vol. 44 No. 1. The authors are grateful to Perrine Toledano for her input and thorough review and to Joseph Bell and Jeff Wood for their comments on an earlier draft.

1 David N. Smith and Louis T. Wells Jr., Negotiating Third World Mineral Agreements, Promises as Prologue (Cambridge, Mass.: Ballinger Pub. Co., 1975).

2 Petrocash legal database <www.petrocash.com/Legal/>accessed 6 March 2014, and contracts collected by CCSI. 
by the Liberia Extractive Industries Transparency Initiative (LEITI) ${ }^{3}$ and the Model Mine Development Agreement prepared by the International Bar Association in 2011 (MMDA). ${ }^{4}$ With regard to the legislative approach, Tanzania's Mining Code is one example (and the only one readily available) of legislation that contains such a mechanism. ${ }^{5}$ The Periodic Review Mechanisms in the Liberian contracts are broadly representative of the examples in the MMDA. This article analyses the Liberian contracts in order to better understand such mechanisms. ${ }^{6}$

While the focus of this article is on Periodic Review Mechanisms (Section 3 ), the fourth section will consider mechanisms that are not initiated periodically but at the request of one of the parties (At Request Review Mechanisms), providing additional insight into the issue of the parties' obligations to modify the contract (Section 4). Section 5 identifies problems that arise in practice under Periodic Review Mechanisms and Section 6 outlines a new approach to the review of contracts. The section further provides objective criteria for the parties to determine whether a renegotiation should occur and, if so, the parameters of the renegotiation. The final section will look at strengths and weaknesses of the Periodic and At Request Review Mechanisms, and suggest ways to strengthen obligations if the parties so decided.

3 See < www.leiti.org.lr/>accessed 6 March 2014. For the purpose of this analysis, the contracts were categorised and numbered as set out in Annex 2.

4 The MMDA contains a model Periodic Review Mechanism and provides four examples, one of which comes from a Liberian contract, another is taken from the Australian Adnyamathanha Body Corporate Indigenous Land Use Agreement <www.pir.sa.gov.au/_data/assets/pdf_file/0009/175671/ Adnyamathanha_Minerals_Exploration_ILUA_13.2.12.pdf $>$. The source of these other clauses in the MMDA is unknown. The Periodic Review Mechanism in the Australian contract is conceptually different from the Liberian mechanisms. Unlike the Liberian mechanisms, it is not part of an investment contract but found in a land use agreement in which the parties agree to consent to the grant of authorised exploration contracts (clause 3.1(a)(i)). The government of South Australia has published three additional land use agreements with similar periodic review mechanisms.

5 Tanzania Mining Code, Part II, 12 provides for periodic review: "The development agreement entered into under section 10 shall be subject to periodic performance review by parties after every five years".

6 By 25 September 2013, LEITI had published and categorised over 119 contracts according to their industry: 76 forestry contracts, 19 mining contracts, 14 agriculture contracts and nine oil contracts. For this analysis, we analysed one additional mining contract and one additional oil contract that were not published by LEITI. 


\section{REVIEW MECHANISIMS - OVERVIEW}

Annex 1 sets out clauses containing review mechanisms from two contracts (Mining Contract 2 and Oil Contract 10). Each contains three types of review processes (which are not mutually exclusive), broadly described as follows:

a. A regular meeting between the parties, once every five (5) years, to discuss in good faith, whether any modifications are required to the terms of the contract in light of "any substantial changes in circumstance" (in Oil Contract 10, this periodic meeting only occurs if a party requests it with 45 days' notice). This review process is herein referred as "Periodic Review", as it envisages a meeting between the parties at regular intervals.

b. An "on-demand" meeting, if either party makes a request on the basis that a particular event (Trigger Event) has occurred such that the contract requires modifications. In the examples in Annex 1, the Trigger Event is a "Profound Change of Circumstance" (PCC described in Section 3.2 below). The parties must meet to determine whether a PCC has occurred, and if so must discuss in good faith any changes required to the contract. This review process is referred to in this brief as "Trigger-At-Request-Review", as the meeting may take place at any time upon a party's request, but the parties only discuss changes to the contract if they establish that a particular Trigger Event has occurred (i.e., PCC).

c. An "on-demand" meeting at any time that a party requests, to discuss any matter "affecting the rights and obligations of the parties". The parties must discuss in good faith the matter raised. This type of review process is referred to in this brief as an "Automatic-At-RequestReview" as either party can request it at any time without the need to establish a Trigger Event.

These different review processes broadly represent the procedures set forth in many of the contracts reviewed herein, although each contract's provisions may vary slightly from the above requirements.

In the contracts evaluated, the "Review Process" can be described by the following elements:

a. "Initiation of the Review" (3.1 and 4.1) - in regular meetings at defined intervals (3.1) or in ad hoc meetings at the request of one of them (4.1.), the parties start the Review Process. The Review Process does not necessarily lead to the parties actually discussing changes to the contract. 
b. "Modification Process" (3.2, 3.3 and 4.2, 4.3) - the process during which the parties consider in good faith and possibly make modifications to the contract, as they agree, is necessary in light of changed circumstances.

c. "Trigger Event" (3.2 and 4.2) - a particular circumstance that the parties during the Review Process must agree to has occurred before they enter into the Modification Process. In case that the particular circumstance has not occurred, the Review Process stops and a Modification Process does not proceed. For some At Request Review Mechanisms, it is not necessary to establish a Trigger Event before commencing the Modification Process.

d. "Obligations of the parties" (3.3 and 4.3) - the parties' obligations during the Modification Process, typically to discuss the matters raised and to consider in good faith possible changes to the contract.

\section{PERIODIC REVIEW IN LIBERIAN CONTRACTS}

In the contracts reviewed for this article, seven out of 20 Mining Contracts ${ }^{7}$ and two out of the 10 Oil Contracts ${ }^{8}$ contain Periodic Review Mechanisms.

\subsection{Initiation of the Periodic Review}

At pre-defined intervals over the course of the investment, the parties are required to meet and consult, with the aim of establishing whether or not a Trigger Event has occurred. In all but one of the Liberian Mining Contracts, ${ }^{9}$ as well as in the two Oil Contracts with Periodic Review Mechanisms, this interval is five years. ${ }^{10}$

\subsection{Trigger Event in Periodic Review}

The Trigger Event is a crucial element of the Periodic Review Mechanisms, because it starts the Modification Process. In order for a Modification Process to take place, the parties must agree that the Trigger Event has occurred (which is not a given). Typically, the Trigger Event can only be inferred from

7 Mining Contracts 1, 2, 5, 12, 14, 15, 17.

8 Oil Contracts 5 and 10.

9 In Mining Contract 5b the interval is "not less than every 7 years".

10 Mining Contract 1, 2, 12, 14, 20, and 15, which specifies "or earlier" and is therefore similar to Mining Contract 5; Oil Contract 5, Article 36.3, and Oil Contract 10, Article 36.2(c). Oil Contract 10 also specifies a 45-day notice period. 
the Periodic Review Mechanisms. In these cases, it is defined as "any substantial changes in circumstances." 11 Other contracts, however, are explicit in requiring a Trigger Event, defined in more detail: in order for the Modification Process to begin the parties must establish the occurrence of PCC. ${ }^{12}$ PCC is generally defined as:

such changes [...] in the economic conditions of the mineral and mining industry worldwide or in Liberia, or such changes in the economic, political or social circumstances existing in Liberia specifically or elsewhere in the world at large as to result in such a material and fundamental alteration of the conditions, assumptions and bases relied upon [...] that the overall balance of equities and benefits reasonably anticipated by them will no longer as a practical manner be achievable.

If the parties fail to agree that the Trigger Event has occurred, the Review Process terminates. The contracts reviewed herein generally do not specify whether (or not) the dispute over the existence of a Trigger Event can or should be arbitrated. One contract, Oil Contract 10, explicitly provides that the clauses dealing with the Review Process will not be subject to the contract's dispute resolution provisions. If the parties agree, the Modification Process begins and the obligations of the parties relative to this process are triggered.

\subsection{Obligations of the Parties during the Periodic Review}

Typically, the obligation of one party to negotiate and accept a proposal to modify the contract made by the other party during the Modification Process is relatively weak: parties are only required to enter into discussions in good faith. ${ }^{13}$ Exceptionally, contracts provide sanctions to persuade the other party to negotiate and accept proposals for modification from the other party(ies). One contract provides that certain tax exemptions expire unless they are renewed during the Review Process:

11 Mining Contract 2, Article 30.2: "This Agreement shall be subject to periodic review once every (5) years after the date of the start of Production for the purpose of good faith discussions to effect such modifications to this Agreement as may be necessary or desirable in the light of any substantial changes in circumstances which may have occurred during the previous five years."

12 Mining Contracts 15 and 20.

13 Mining Contract 1, Article 35.1: "It is understood that this clause subjects the Parties to a simple obligation to consider in good faith the proposed modification of the Agreement [...] This Agreement shall remain unaltered and in force during any such period of consideration." 
Not less than every 7 years after the commencement of commercial production, the parties shall consult together in Liberia for the purpose of considering such changes in or clarifications of this Agreement as either party deems to be appropriate. Unless otherwise renewed in writing by the Government prior to the conclusion of each such consultation, the exemptions provided in Section 16.4 shall expire six (6) months after the date herein provided for the commencement of such consultation [emphasis added]. ${ }^{14}$

The examples of Periodic Review Mechanisms in the MMDA also reveal relatively weak obligations, other than one example, from an Australian land use agreement (see Note iv), which provides that its original terms will not continue if the parties do not reach agreement during the Review Process. ${ }^{15}$

In conclusion, the language used in the Periodic Review Mechanisms clearly leaves, solely in the hands of the parties, a consensus to modify the contract. If there is no agreement, no modification is made. The only real obligation in the majority of contracts is the duty to act in good faith while discussing and considering possible modifications to the contract, but most contracts do not provide parameters as to what will be considered "good faith". One contract that does provide some guidance emphasises that there is no requirement to make any changes: “Good faith discussions' and 'consultation' shall not require a Party to agree to any modifications to this Contract [...]."16 Given this significance ofgood faith discussions, one area for further research would be to analyse how arbitral tribunals treat such a duty and what sort of obligations, if any, may be attached to such duty.

\section{AT-REQUEST-REVIEW IN LIBERIAN CONTRACTS}

As illustrated in Section 2 above, in addition to the Periodic Review Mechanisms, there are two types of At Request Review Mechanisms in the Liberian contracts. Both include a consultation that is initiated by the request of one of the parties. Observably, some clauses require the parties to establish that a Trigger Event has occurred in order to start the Modification Process

14 Mining Contract 5, Article 33.

15 Model Mine Development Agreement 1.0., Clause 36.0. Australian land use agreement is example 4.

16 Oil Contract 10, Article 36.2(f). 
when the parties meet (Trigger-At-Request-Review), while for others, the request itself sets the Modification Process in motion (Automatic-At-Request-Review). The obligations of the parties to agree to any modifications to the contract are weaker for the Automatic-At-Request-Review than for the Trigger-AtRequest-Review.

\subsection{Initiation of the At Request Review}

Both At-Request-Review Mechanisms can be initiated following the request of one of the parties, at any time. In Trigger-At-Request-Review mechanisms, the request usually must be based on the perception by the party making the request that a particular Trigger Event has occurred (i.e., PCC). In all cases, the parties only discuss changes to the contract if they agree that a Trigger Event has occurred.

\subsection{Trigger Event in Trigger-At-Request-Review}

In the Liberian contracts, the Trigger Event of the Trigger-At-Request-Review Mechanism is always defined as PCC. The definition of PCC differs slightly between the Mining and Agriculture Contracts, on the one hand and the Oil Contracts, on the other hand. The Mining Contracts and Agriculture Contracts use almost identical language to define PCC as:

such changes...in the economic conditions of the mineral and mining industry worldwide or in Liberia, or such changes in the economic, political or social circumstances existing in Liberia specifically or elsewhere in the world at large as to result in such a material and fundamental alteration of the conditions, assumptions and bases relied upon by the parties at such base period that the overall balance of equities and benefits reasonably anticipated by them will no longer as a practical manner be achievable [emphasis added]. ${ }^{17}$

The Oil Contracts, however, refer to changes in "economic conditions" and then more broadly to changes, without any limitation to changes in the "economic, political or social circumstances." There is only one exception to

17 Oil Contract 2, Article 35.3. 
this pattern in the Oil Contracts, found in the most recent contract from 2013, which is similar to the Mining and Agriculture Contracts. ${ }^{18}$

\subsection{Obligations of the Parties during the At-Request-Review}

The obligations of the parties during the Modification Process of the TriggerAt-Request-Review clauses are very similar to those in the Periodic Review clauses. In general, a requirement that the parties make any changes that they agree "in good faith" is necessary. ${ }^{19}$ Automatic-At-Request-Review clauses provide even weaker obligations for the parties to agree to any modification proposals made by the other side: "the parties shall take such action, if any, that is mutually agreed to address the matter." ${ }^{20}$

\section{ISSUES ENCOUNTERED IN PRACTICE}

As this assessment indicates, many Periodic Review clauses have very broad and imprecise wording. This gives rise to disagreements over whether or not the circumstances alleged by one party can justify a renegotiation or whether or not a Trigger Event has occurred. Thus, instead of negotiating new financial terms and work schedules, for example, the parties exhaust much time, effort and initial goodwill arguing over the pertinence and reality of the facts alleged by one of the parties. Over time, goodwill often turns to bad faith negotiations

18 Oil Contract 10, Article 36.2(b): "For the purposes of this Article 36.2, "Profound Change in Circumstances" means such changes [...] in the economic conditions of the petroleum industry worldwide or in Liberia, or such changes in the economic, political or social circumstances existing in Liberia specifically or elsewhere in the world at large as to result in such a material and fundamental alteration of the conditions, assumptions and bases relied upon by the Parties at the Relevant Date that the overall economic, fiscal and financial balance reasonably anticipated by them will no longer as a practical matter be achievable."

19 Some Oil Contracts provide additional details and specify "that the economic benefits to the Parties shall not be reduced as a result of exercising the terms of this Article" (Oil Contract 2, Article 35.3, 2005). While the aim is to restore the equilibrium that was initially intended by the parties the re-equilibration is not automatic, but subject to the agreement of the parties. Other contracts require the parties to "make the necessary revisions and adjustments to this Contract in order to offset or alleviate the said economic hardship caused by such change, maintain such expected economic benefits to each of the parties, recognising the risk which is it has been undertaken by the Contractor under this Contract, provided that the economic benefits to the Parties shall not be reduced as a result of exercising the terms if this Article." (Oil Contract 4, Article 35.3).

20 Mining Contract 2. 
with allegations that the numbers produced by one of the parties are not trustworthy and cannot be relied upon as the basis to renegotiate terms and conditions. The higher the financial stakes, the more unlikely the parties will agree that events have resulted in a grave disequilibrium in the contract conditions.

The parties use many arguments to justify the status quo, depending on which party has benefited from the alleged change in circumstances.The investor, who benefits from a windfall profit, often will argue against a renegotiation requested by the Government by stating that the sudden rise in prices of the commodity (for example) was foreseeable in long-term contracts and that the newfound profit is a fair return for the assumed project risk. Moreover, (s)he will argue that since it pays more taxes (if such is the case), the Government benefits from the increased tax revenue.

If the issue is a prolonged investor loss as opposed to a windfall profit, the investor often will argue that unforeseeable geological challenges or a drop in the commodity prices (for example) makes its investment worthless or much less valuable to it, thereby setting the scene for a work stoppage to force negotiations. Similarly, the same argument can be made in the case of government-initiated modifications to the tax regime in the absence of freezing or stabilisation clauses. In response to commodity price decreases or geological challenges, the government can argue that a sharp rise or fall in commodity prices is foreseeable (even if it is forced to admit that the timing and extent of the variations in price are not) and that the investor assumed the risk of geological challenges.

In order to mitigate or eliminate government-initiated modifications in the tax regime, investors most often require tax stabilisation, which affords foreseeability at least for one of the elements used to calculate the return on investment (ROI). However, such stabilisation does not address all of the other variables in long-term extractive industry contracts.

Although the above arguments appear reasonable, depending upon which party is making them and under which circumstances, a government may be reluctant to sit down with investors to readjust royalties, tax benefits and the like when prices fall and/or the quality or quantity of the commodity is less advantageous than forecast and/or the geology turns out to be much more difficult than foreseen. Similarly, an investor will hesitate to discuss with the government, readjusting financial terms when it is experiencing windfall profits.

\section{A NEW APPROACH}

\subsection{The Approach - Setting Objective Criteria}

Circumscribing the scope of negotiations and accusations of the use of 
unreliable data, by using objective criteria and supporting financial data to calculate a base line for the parties' financial expectations may increase the chance of success in Periodic Reviews. The purpose of the base line calculations is to share the partners' financial expectations at the beginning of the project. These expectations would be re-examined by comparing the base line figures with actual figures at contractually defined intervals or at party requested intervals or both, to ascertain whether circumstances have resulted in the financial reality for one or several of the parties being very far off the base line expectations such that renegotiations are warranted. If the investor's projections turn out to be wildly off base, it is likely that the government's revenue projections will be as well, thereby giving the parties a reality based incentive to renegotiate.

The base line calculations would be attached to the contractual framework when it is first negotiated and signed. For example, in the Schedule setting out the investor's requirements (work schedules, amounts to be invested, etc.), he could set out its expected ROI for each phase of the project (feasibility study, exploration, infrastructure construction, commercial production and sale phases of the project, etc.). The more information and data shared by the investor in calculating its ROI, the more reliable the base line will be.

The investor's base line could take the form of a mathematical formula wherein its numbers affecting the future profitability of the project are inserted (CAPEX, OPEX, financial costs not accounted for in the CAPEX, projected average sale price of commodity, etc.), to predict a projected ROI during each of the major phases of the project (which could be a loss for example for the feasibility and exploration stage). This method would not necessarily require the investor to divulge all of the detailed data used to calculate its projected CAPEX and OPEX, but it would hold the investor responsible for its projected base line ROI for each stage of the project, in order to evaluate whether or not the financial and other conditions of the contract should be renegotiated.

The government on its part would be required to attach the projections of revenue from royalties, land fees, taxes, etc., and the time line for their receipt to the contractual framework. The government calculations will, to a large extent, rely on the investor's projections of quantities, quality and sale price, but the government could conceivably arrive at its revenue projections through independent analysis, which is always preferable to relying solely on the investor's figures.

\subsection{Data Required}

To ensure reliable long-term numbers, the data for each stage of the project 
would be input into the formula during each stage of the project and the cumulated ROI would be exchanged by the parties at contractually defined periods during each project stage or upon the request of one of the parties or both. If the resulting ROI calculations vary by more than one or several negotiated fixed percentage(s), the parties would be obligated to renegotiate in order to attain or readjust their respective expectations as set forth in the initial contractual framework. The parties could also decide to modify the base line figures and the percentage of difference that will trigger a renegotiation. Moreover, different percentages could be used for various stages of the project; if the parties feel that the application of one sole percentage (difference of more or less than 10\% of the base line ROI, for example) would not take into account all of the variables. Furthermore, the percentage should be applied in both upturn and downturn situations: ROI higher or lower than that projected in the contractual documents.

The factors which can be renegotiated are numerous: tax holidays, incentives, rates, customs duties, depreciation methods, royalty rates, income tax, land fees, fees on transportation infrastructure (if a fee sharing method has been adopted for rail cars, highways etc), when these issues are set forth in contractual arrangements, rather than in the country's law. The permit's validity period and work obligations could also be adjusted to permit a longer (or shorter) period for the recovery of CAPEX by the investor.

\subsection{Detailed Financial Information Required}

A major issue in the negotiation of extractive contracts is the unequal knowledge base of the contracting parties. Investors inevitably have more information at hand to make savvy investment decisions. Governments, on the other hand, have difficulty getting evaluations of their mineral or hydrocarbon reserves from neutral third parties due to cost constraints, as they do not have easy access to the economic and financial experts needed to construct realistic tax, royalties, production sharing and other essential economic and financial projections. ${ }^{21}$

The primary purpose of setting forth detailed financial expectations in the contractual framework is to permit the parties to set a mutually agreed base line for financial returns for each of the parties. The numbers and assumptions used by investors and their lenders to decide whether or not to invest are crucial information which, if shared in a confidential, commercially

21 Whereas pro bono legal experts exist, it is not easy to find qualified pro bono economic and financial experts. 
constructive manner, would serve to build trust between the partners in the investment and allow for renegotiations based on objective criteria depending upon the stage of the project and which party has incurred the cost: the cost of digging/drilling/excavation, the cost of bringing water and electricity to the site, the cost of relocating populations, the quality of the commodity extracted which will affect its sale price, the actual tonnage which can be extracted at a reasonable rate of ROI, the cost of transportation of the commodity to bring it to sale to third parties, etc.

The same is true for the government: the calculations by the government economists of tax and royalty revenue and other financial considerations must be taken into account in order to evaluate whether or not the numbers for the royalty percentage, land fees, income tax rate calculations, etc. are reasonable and close to accurate or mistaken, grossly erroneous, and so forth.This would facilitate negotiations based on the parties' real interests and not on secret and undocumented calculations. This "mathematical" method would have an additional advantage of forcing the contracting parties to be transparent and share their knowledge and financial expectations.

\subsection{Dealing with Confidentiality}

A key problem with this approach is convincing investors to share their information and know-how, which is often considered proprietary. Certain investors understandably will not want to divulge such information. Observably, if information, data and financial projections can be "sanitised" and if the other partners/parties are obliged to respect confidentiality subject to stiff automatic penalties, there may be room for the exchange of sufficient data to make this method work.

For example, the data used to establish feasibility studies could be licensed to the government on an exclusive basis for a modest fee. This could give the data the intellectual property protections required to reassure the investor, while giving the government access to valuable information concerning its own reserves. The licence fee could be incorporated into the royalty for a fixed period of time. To make this type of arrangement work, the investor would have to communicate to the government the cost of the feasibility study. In this way, the government's payment for its use makes commercial sense. Perhaps, the government would want to purchase the data and the feasibility study for its cost plus a small percentage. At the very least, the parties can give the data and the feasibility study a value to be taken into account when calculating the ROI of the investor and the ROI of the government. 


\section{CONCLUSIONS}

The importance of review provisions rests in their ability to maintain dialogue between the parties and to create an opening to discuss changed circumstances and the potential for revision, in situations that perhaps the parties could not have listed with any specificity at the outset. The Periodic Review Mechanisms identified tend to impose an obligation to discuss; the parties are required to meet and consult, but there is little obligation for them to make any changes to the contract during a review. In many cases the only requirement is that the parties act in good faith. While the contracts reviewed rarely define "good faith" in this context, it would be worthwhile considering how arbitral tribunals have interpreted this term. Further, most Review Mechanisms provide for the continuation of the original contract provisions if the parties fail to agree to any modification, adding to the lack of bite that some practitioners attribute to Periodic Review Mechanisms.

A number of contracts contain three separate avenues for consultation between the parties. Given the absence of obligations in each to do more than hold good faith discussions, the question may be raised as to whether the potential use of three different procedures is efficient and constructive.

If the parties do wish to ensure that contract modification is seriously considered during each consultation, stronger obligations need to be included during the Modification Process. The review did reflect some options. As stated above, one clause stipulated that certain tax exemptions would expire unless they are renewed by the agreement of the parties during the review process. This type of clause would provide impetus to the investor to enter into serious discussions in relation to the contract terms. Such a mechanism could potentially be extended to other provisions of the contract that are perceived as likely to require adaptation over the duration of the investment, such as any tax or royalty rate, especially if they are fixed, and any exemptions. ${ }^{22}$ The Periodic Review Mechanism in the Australian land use agreement (see Note iv) provides that if the parties fail to reach an agreement - either to modify, or not to modify the agreement - no further exploration contracts can be entered into pursuant to the land use agreement. ${ }^{23}$ The Mining

22 See Mining Contract 5.

23 2.2(e)(i): If no agreement has been made "no accepted exploration contract may be entered into pursuant to clause 5.1 of the exploration contract conditions". In this example, however, the rights and obligations of the parties to existing exploration contracts are not impacted: 2.2(f)(ii): 2.2(e) "does not in any way affect [...] any accepted exploration contracts entered into prior to the relevant date." 
Sector Business Association, which is party to the land use agreement and represents the mining companies, thus has an interest in reaching an agreement under the Periodic Review Mechanism if it does not want to harm the future business of its members.

Furthermore, Periodic Review Mechanisms could define clear standards and criteria for the parties to follow during the Modification Process. Some of the Oil Contracts, notably Oil Contract 4, are more explicit regarding the intended outcome of a modification ("offset or alleviate the said economic hardship caused by such change [PCC]"). Smith and Wells suggest the following formulation, which provides some parameters around the issue of determining whether a change should be made:

In undertaking such review, the Parties shall bargain in good faith with a view toward providing a fair and equitable division of profits in light of the economic factors prevailing at the time of the review.

In undertaking such review the Parties shall be guided by, but not limited to, consideration of the following factors:

1. The economic value of the concession.

2. Terms of other (nickel) agreements negotiated by the government within the five-year period preceding the date of review.

3. Terms of other (nickel) agreements negotiated by the Concessionaire within the five-year period preceding the date of review.

4. Terms of other (nickel) agreements negotiated by third parties to the extent that such agreements can be reasonably compared to this Agreement. ${ }^{24}$

Alternatively, an entirely new approach could be adopted whereby the parties share, at the outset, their financial expectations over the course of the project to create a baseline reflecting these expectations. This baseline can be reviewed over the duration of the project in order to determine, objectively, whether there is a need for renegotiation - in cases where either party's financial expectations are not being met.

Despite their problems, Periodic Review Mechanisms can still play an important role. These mechanisms can be the only provision under which a government can request changes to the terms of the contract where the balance

24 Smith and Wells Jr (n 3). 
of benefits changes in light of changed circumstances. For example, it was suggested by practitioners that the mechanisms could add legitimacy to a request by a government for amendments when changed circumstances in the market result in the investor receiving an unexpected level of profit. This contrasts with other mechanisms that often apply unilaterally to the investor, providing for adjustment to the contract terms to restore the economic equilibrium expected under the contract, where there has been a change (generally government legislation) affecting the investor's share of benefits. ${ }^{25}$

On the part of the investor, Periodic Review Mechanisms can be used internally to convince others within the company that changes are necessary, where they are seen as desirable for business or political purposes. From this perspective, the mechanisms can provide a legal underpinning for parties seeking to achieve a business or relationship imperative. In any event, the Review Mechanism may play an important role in managing the relationship between the parties and in particular in managing the process of renegotiation. At the very least, they act to keep the parties talking to each other over the course of the investment.

To better understand the usefulness of the current form of Periodic Review Mechanisms in practice, further research could track renegotiations or attempted renegotiations under contracts that contain such provisions against those that do not. This could reveal the effect of the clause on the outcome and the process of renegotiation, as well as the recourse to arbitration.

25 Such as stabilisation clauses, including freezing clauses and economic balancing clauses. For a description of these clauses, see for example: Frank Alexander, "Comment on articles on stabilisation by PieroBernardini, Lorenzo Cotula and AFM Maniruzzaman” (2009) 2(3), Journal of World Energy Law \& Business, p. 244. 


\section{Annex 1 \\ Review Mechanisms in Mining Contract 2 and Oil Contract 10}

Mining Contract 2 - Section 30 - Periodic Review

30.1 Profound Changes in Circumstances. For the purpose of considering Profound Changes in Circumstances from those existing on the Effective Date or on the date of the most recent review of this Agreement pursuant to this Section 30, the Government on the one hand and the Concessionaire and the Operating Company jointly on the other hand, shall at the request of the other consult together. The parties shall meet to review the matter raised as soon after such request as is reasonably convenient for them both. In case Profound Changes in Circumstances are established to have occurred, the parties shall effect such change in or clarification of this Agreement that they in good faith agree is necessary.

30.2 Five Year Review. This Agreement shall be subject to periodic review once every five (5) years after the date of the start of Production for the purpose of good faith discussions to effect such modifications to this Agreement as may be necessary or desirable in the light of any substantial changes in circumstances which may have occurred during the previous five years.

30.3 Other Consultation. In addition to the consultation and review provided by Section $30[\ldots]$, each party may at any time request a consultation with the other party with respect to any matter affecting the rights and obligations of the parties pursuant to this Agreement or any matter relating to Operations. The parties shall meet to review in good faith the matter raised as soon after such request as is reasonably convenient for them both. Subsequent to such consultation, the parties shall take such action, if any, that is mutually agreed to address the matter."

Oil Contract 10 - Section 36.2 Profound Change in Circumstances

(a) The State and the Contractor shall meet if the State or the Contractor gives at least forty-five (45) days' Notice to the other that it reasonably considers a Profound Change in Circumstances to have occurred. At the meeting, the State and the Contractor shall review the relevant facts and circumstances and determine whether or not a Profound Change in Circumstances has occurred. To the extent that a Profound Change in Circumstances has occurred, the State and the Contractor shall enter into good faith discussions to consider and shall make such modifications to this Contract as they may through good faith discussions propose as necessary or appropriate to restore the economic, fiscal and financial balance of the Contract... 
(c) In addition to the review provided for in Article 36.2(a), the State and the Contractor shall also meet once every five (5) years after the Effective Date, on at least forty five (45) days' prior Notice at the request of either, to review and discuss in good faith issues deemed material to the rights and obligations of the State and the Contractor pursuant to this Contract by the requesting party. The Parties shall effect such modifications to this Contract that the Parties in good faith discussions agree are necessary.

(d) In addition to the consultation and review provided by Articles 36.2(a) and 36.2(b), either the State or the Contractor may at any time request a consultation with the other Party with respect to any matter affecting the rights and obligations of the State and the Contractor pursuant to this Contract. The State and the Contractor shall meet reasonably promptly after such request for the requested consultation. Subsequent to such consultation, the Parties shall take such action, if any, that is in good faith discussions mutually agreed to address the matter.

(e) Any Notice or request under Articles 36.2(a) through 36.2(d), inclusive, shall include a summary statement of the circumstances giving rise to such Notice or request.

(f) For the purposes of Articles 36.2(a) through 36.2(d), "good faith discussions" and "consultation" shall not require a Party to agree to any modifications to this Contract and the lack of agreement is not subject to Article 31 [i.e., dispute resolution]. 


\section{Annex 2}

\begin{tabular}{|c|c|c|}
\hline $\begin{array}{l}\text { Contract } \\
\text { No. }\end{array}$ & Mining Contracts & Signing Date \\
\hline 1 & $\begin{array}{l}\text { Mineral Development Agreement between The } \\
\text { Republic of Liberia and KPO Resources } \\
\text { Incorporated }\end{array}$ & $\begin{array}{l}28 \text { November } \\
2001\end{array}$ \\
\hline 2 & $\begin{array}{l}\text { Mineral Development Agreement between the } \\
\text { Government of the Republic of Liberia, China- } \\
\text { Union (Hong Kong) Mining Co., Ltd. and } \\
\text { China-Union Investment (Liberia) Bong Mines } \\
\text { Co., Ltd. }\end{array}$ & $\begin{array}{l}19 \text { January } \\
2009\end{array}$ \\
\hline 3 & $\begin{array}{l}\text { Mineral Exploration Agreement between The } \\
\text { Republic of Liberia and African Aura Resources } \\
\text { Limited }\end{array}$ & 14 March 2002 \\
\hline 4 & $\begin{array}{l}\text { Iron Ore Exploration Agreement for the Kitoma } \\
\text { Range between The Republic of Liberia and } \\
\text { BHP Billiton World Exploration Inc. }\end{array}$ & 11 May 2005 \\
\hline 5 & $\begin{array}{l}\text { An Act Approving the Mining Concession } \\
\text { Agreement entered into by and between } \\
\text { Government of the Republic of Liberia and } \\
\text { Bentley International Trading Corporation }\end{array}$ & 23 May 1978 \\
\hline 6 & $\begin{array}{l}\text { Mineral Exploration Agreement II between The } \\
\text { Republic of Liberia and Deveton Mining } \\
\text { Company }\end{array}$ & $\begin{array}{l}22 \text { September } \\
2005\end{array}$ \\
\hline 7 & $\begin{array}{l}\text { Iron Ore Appraisal and Mineral Exploration } \\
\text { Agreement for the Putu Range between The } \\
\text { Republic of Liberia and Mano River Iron Ore } \\
\text { (Liberia) Inc. }\end{array}$ & 18 May 2005 \\
\hline 8 & $\begin{array}{l}\text { Mineral Exploration Agreement between The } \\
\text { Republic of Liberia and Liberty Gold and } \\
\text { Diamond Mining Inc. }\end{array}$ & $\begin{array}{l}26 \text { October } \\
2005\end{array}$ \\
\hline 9 & $\begin{array}{l}\text { Mineral Exploration Agreement between The } \\
\text { Republic of Liberia and G-10 Exploration Inc. }\end{array}$ & $\begin{array}{l}26 \text { October } \\
2005\end{array}$ \\
\hline 10 & $\begin{array}{l}\text { Mineral Exploration Agreement between The } \\
\text { Republic of Liberia and T-REX Resources Inc. }\end{array}$ & $\begin{array}{l}20 \text { October } \\
2005\end{array}$ \\
\hline 11 & $\begin{array}{l}\text { Mineral Exploration Agreement between The } \\
\text { Republic of Liberia and Golden Ventures Inc. }\end{array}$ & $\begin{array}{l}26 \text { October } \\
2005\end{array}$ \\
\hline 12 & $\begin{array}{l}\text { Mineral Exploration Agreement between The } \\
\text { Republic of Liberia and Amlib United Minerals } \\
\text { Inc. }\end{array}$ & 14 March 2002 \\
\hline 13 & $\begin{array}{l}\text { Concession Agreement Between the Republic } \\
\text { of Liberia and the Liberia Company }\end{array}$ & \\
\hline 14 & $\begin{array}{l}\text { Mineral Development Between the } \\
\text { Government of Liberia and Bea Mountain }\end{array}$ & $\begin{array}{l}28 \text { November } \\
2001\end{array}$ \\
\hline 15 & $\begin{array}{l}\text { An Act to Ratify the Concession Agreement } \\
\text { Between the Republic of Liberia and Western } \\
\text { Cluster Limited, Sesa Gao Limited, Bloom } \\
\text { Fountain Limited, And Elenilto Minerals and } \\
\text { Mining LLC }\end{array}$ & 22 August 2011 \\
\hline
\end{tabular}


16

17

18

19

20
Mineral Exploration Agreement between the Republic of Liberia and Magma Mineral

Resources Inc.

An Act Ratifying the Amendment to the Mineral Development Agreement (MDA) Dated

17 August 2005 between the Government of the Republic of Liberia (The Government) and Mittal Steel Holding A. G. and Mittal Steel (Liberia) Holdings Limited (The

Concessionaire)

Mineral Exploration Agreement between The Republic of Liberia and Craton Developments

Inc.

Iron Ore Appraisal and Mineral Exploration Agreement for the Goe-Fantro Range between The Republic of Liberia and BHP Billiton World Exploration Inc.

Mineral Development Agreement Between the Government of the Republic of Liberia and BHP Billiton Iron Ore Holdings
26 October

2005

28 December

2006

26 October

2005

22 April 2005

16 September 2010 


\begin{tabular}{|c|c|c|}
\hline $\begin{array}{l}\text { Contract } \\
\text { No. }\end{array}$ & Oil Contracts & Signing Date \\
\hline 1 & $\begin{array}{l}\text { An Act Ratifying the Production Sharing } \\
\text { Contract Between the National Oil Company of } \\
\text { Liberia, Oranto \& Chevron-LB } 14 \text { Second } \\
\text { Addendum }\end{array}$ & $\begin{array}{l}\text { 3 September } \\
2010\end{array}$ \\
\hline 2 & $\begin{array}{l}\text { Production Sharing Contract Between GOL, } \\
\text { Regal Liberia Ltd \& Hydrocarbons Ltd. }\end{array}$ & $\begin{array}{l}11 \text { March 2008, } \\
\text { approved by } \\
\text { President }\end{array}$ \\
\hline 3 & $\begin{array}{l}\text { An Act Ratifying the Production Sharing } \\
\text { Contract with Addendum for Offshore Liberia } \\
\text { Blocks LB } 16 \text { \& } 17 \text { Signed Between the } \\
\text { Republic of Liberia Represented by the } \\
\text { National Oil Company of Liberia (NOCAL) and } \\
\text { REPSOL Exploration S.A. }\end{array}$ & 17 August 2005 \\
\hline 4 & $\begin{array}{l}\text { An Act Ratifying the Production Sharing } \\
\text { Contract with Addendum for Offshore Liberia } \\
\text { Blocks LB } 15 \text { Signed Between the Republic of } \\
\text { Liberia Represented by the National Oil } \\
\text { Company of Liberia (NOCAL) and Woodside } \\
\text { West Africa PTY. LTD. }\end{array}$ & 11 March 2009 \\
\hline 5 & $\begin{array}{l}\text { Production Sharing Contract Between the } \\
\text { Republic of Liberia and Hong Kong Tongtai } \\
\text { Petroleum International Corporation Ltd for } \\
\text { Offshore Block LB6 and for Block LB7 }\end{array}$ & Draft \\
\hline 6 & $\begin{array}{l}\text { An Act to Ratify the Production Sharing } \\
\text { Contract for Block LB-10 Signed Between the } \\
\text { National Oil Company of Liberia (NOCOL) on } \\
\text { Behalf of the Republic of Liberia and Anadarko } \\
\text { Liberia Block } 10 \text { Company }\end{array}$ & 23 July 2009 \\
\hline 7 & $\begin{array}{l}\text { An Act Ratifying the Production Sharing } \\
\text { Contract with Addendum for Blocks LB } 13 \\
\text { Signed Between the National Oil Company of } \\
\text { Liberia (NOCAL) on Behalf of the Republic of } \\
\text { Liberia and Broadway Consolidated Plc }\end{array}$ & 31 May 2005 \\
\hline 8 & $\begin{array}{l}\text { An Act to Ratify the Production Sharing } \\
\text { Contract with Addendum for Block LB } 11 \text { and } \\
12 \text { Signed Between the National Oil Company } \\
\text { of Liberia (NOCOL) on Behalf of the Republic } \\
\text { of Liberia and Oranto Petroleum Limited }\end{array}$ & 16 April, 2007 \\
\hline 9 & $\begin{array}{l}\text { An Act to Ratify the Production Sharing } \\
\text { Contract Between the National Oil Company of } \\
\text { Liberia (NOCOL) Representing the Republic of } \\
\text { Liberia and Oranto Petroleum Limited for } \\
\text { Offshore Block LB } 14\end{array}$ & 23 July 2009 \\
\hline 10 & $\begin{array}{l}\text { Block } 13 \text { as amended and restated in } 2013 \text { for } \\
\text { Exxon }\end{array}$ & 8 March 2013 \\
\hline
\end{tabular}

